\title{
Pengukuran dan Pelatihan Kesiapsiagaan Komunitas Sekolah Dasar Muhammadiyah Banyuraden terhadap Bencana Gempa Bumi
}

\author{
Restu Faizah* ${ }^{1}$, Seplika Yadi ${ }^{1}$, Muhammad Ibnu Syamsi ${ }^{1}$, Retnowati Setioningsih ${ }^{2}$ \\ ${ }^{1}$ Program Sudi Teknik Sipil, Fakultas Teknik, Universitas Muhammadiyah Yogyakarta \\ ${ }_{2}^{2}$ Program Studi Teknik Sipil, Fakultas Teknik Sipil dan Perencanaan, Institut Teknologi Nasional \\ Yogyakarta \\ restu.faizah@umy.ac.id
}

Received: $18^{\text {th }}$ April 2020 | Accepted: $30^{\text {th }}$ November 2020 | Published: $30^{\text {th }}$ January 2021

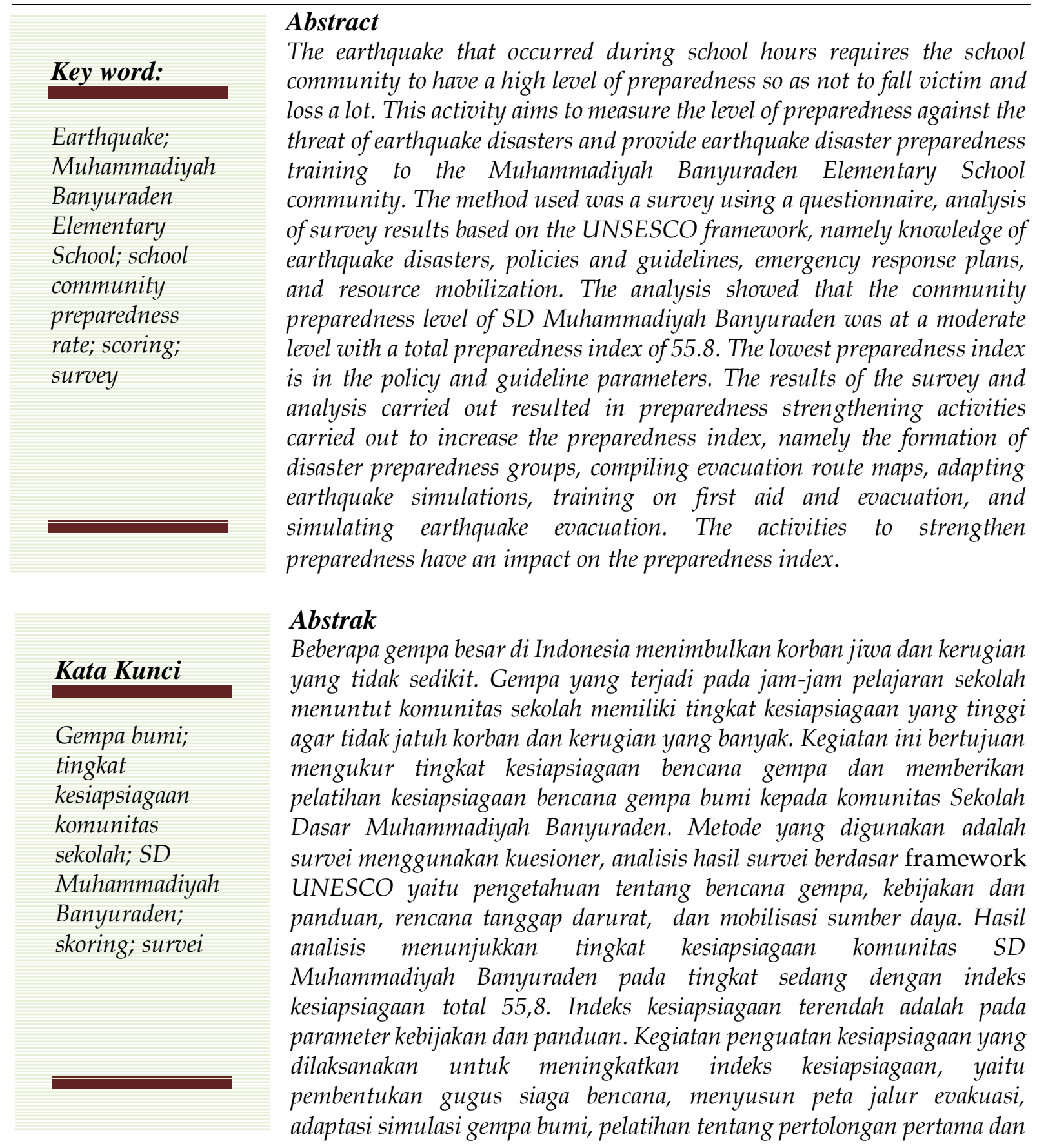


evakuasi, serta simulasi evakuasi bencana gempa bumi. Kegiatan penguatan kesiapsiagaan yang dilakukan memberikan impact bagi indeks kesiapsiagaan.

\section{PENDAHULUAN}

Dalam 15 tahun terakhir, terdapat 46.648 sekolah yang mengalami dampak signifikan akibat bencana alam di Indonesia (Amri, 2017). Salah satu bencana alam tersebut adalah bencana gempabumi Yogyakarta pada tahun 2006, yang menyebabkan 2900 sekolah terdampak.

Sekolah Dasar Muhammadiyah Banyuraden yang terletak di Desa Banyuraden, Kecamatan Gamping, Kabupaten Sleman merupakan salah satu sekolah yang mengalami kerusakan akibat gempa Yogyakarta tahun 2006. Sekolah ini berdiri sejak tahun 1972 dengan SK No. 3029/L1973/DIY.72/77. Saat ini, Sekolah Dasar Muhammadiyah Banyuraden memiliki 12 ruang kelas dan 1 ruang perpustakaan, dengan jumlah guru 17 orang ditambah 1 orang tendik, serta peserta didik sebanyak 318 anak (Kemendikbud, 2019).

Sementara itu berdasarkan hasil penilaian risiko bencana gempabumi oleh Badan Nasional Penanggulangan Bencana (BNPB), wilayah Sleman termasuk dalam kelas risiko tinggi, seperti ditunjukkan dalam peta pada Gambar 1. Wilayah kabupaten Sleman terlihat berwarna merah dengan skor 22 yang berarti memiliki risiko gempa yang tinggi (Kurniawan dkk., 2014). Kondisi ini harus ditindaklanjuti dengan penurunan risiko terhadap bencana gempa, agar kerugian yang mungkin timbul akibat gempa di masa yang akan datang dapat ditekan seminimal mungkin.

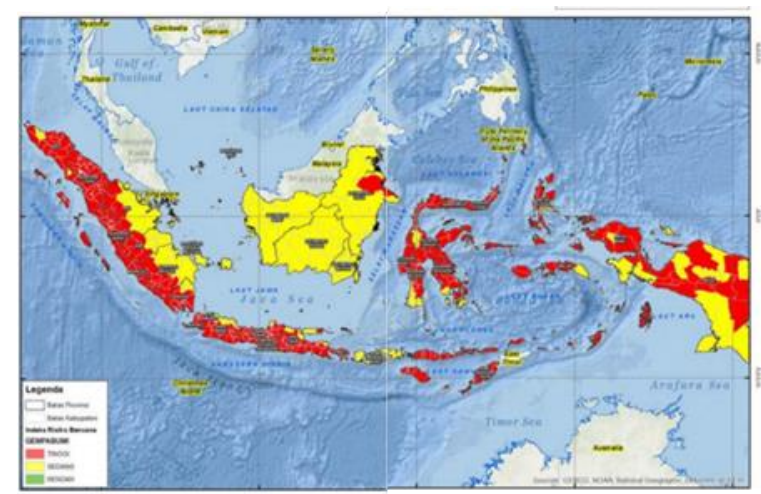

Gambar 1. Peta Indeks Risiko Bencana Gempabumi (IRBI)

Strategi penurunan risiko bencana ini dapat dilakukan dengan strategi peningkatan indeks kapasitas (coping capacity) yang dapat dijalankan melalui aktivitas terukur dengan memperkuat kapasitas penanggulangan bencana pada tiap daerah. Salah satu aktivitas terukur yang paling menentukan adalah perkuatan kesiapsiagaan dan penanganan darurat bencana yang memiliki bobot $35 \%$ diantara semua kegiatan terukur lainnya (BNPB, 2016).

Komunitas sekolah merupakan agen perubahan dan tempat berkumpulnya generasi penerus bangsa, diharapkan dapat berperan serta dalam memperkuat kesiapsiagaan terhadap bencana (Lesmana \& Purborini, 2015). Oleh karena itu, 
pendidikan kesiapsiagaan terhadap bencana alam akan lebih baik jika diberikan sejak dini untuk meningkatkan pengetahuan serta penumbuhkan pemahaman dan kepedulian (Hidayat dkk., 2011).

Pendidikan kesiapsiagaan kepada komunitas sekolah dapat diberikan dengan serangkaian kegiatan yang dilakukan untuk mengantisipasi bencana melalui pengorganisasian serta melalui langkah yang tepat guna dan berdaya guna (UU No. 24 tahun 2007). Sasaran pendidikan kebencanaan pada komunitas sekolah meliputi pengurus, guru, karyawan dan siswa. Kegiatan peningkatan kesiapsiagaan juga dapat dilakukan dalam bentuk kegiatan pelatihan atau simulasi evakuasi, dan pengadaan sarana prasarana kesiapsiagaan (Faizah dkk., 2019).

Penelitian ini merupakan bagian dari kegiatan pengabdian kepada masyarakat yang bertujuan untuk mengukur tingkat kesiapsiagaan komunitas Sekolah Dasar Muhammadiyah Banyuraden dalam mengantisipasi bencana, khususnya bencana gempabumi. Kajian serupa sudah pernah dilakukan di beberapa daerah yang memiliki tingkat kerawanan tinggi terhadap bencana alam, seperti Kota Bengkulu, Kecamatan Aceh Besar, Serang, Cilacap, Sikka, Biak, dan Ternate. Hasil dari kajian menunjukkan bahwa beberapa komunitas sekolah di daerah tersebut masih memiliki tingkat kesiapsiagaan yang sangat rendah

Keadaan seperti ini dinilai sangat berisiko tinggi, terutama apabila bencana terjadi pada saat jam sekolah (Hidayat dkk., 2011)

\section{METODE}

Penilaian kesiapsiagaan komunitas Sekolah Dasar Muhammadiyah Banyuraden terhadap bencana gempabumi meliputi kesiapsiagaan institusi, guru dan siswa, dengan berpedoman pada framework yang dikembangkan oleh LIPI bekerjasama dengan UNESCO/ISDR 2006. Parameter yang diukur meliputi 4 buah parameter, yaitu pengetahuan tentang bencana gempa (knowledge and attitude) (A), kebijakan dan panduan (policies and guidelines) (B), rencana tanggap darurat (emergency planning) (C), dan mobilisasi sumber daya (resource mobilization capacity)

(Hidayat dkk., 2011).

Pengumpulan data yang diperlukan untuk menilai tiap parameter dilakukan dengan cara survei menggunakan metode online melalui google formulir. Sasaran survei terdiri dari 3 kelompok, yaitu kelompok 1 (institusi), kelompok 2 (guru), dan kelompok 3 (siswa kelas 4 dan 5). Metode analisis menggunakan skoring atau penilaian Indeks dengan memperhatikan bobot tiap parameter menurut framework yang dikembangkan oleh LIPI dengan beberapa penyesuaian, seperti ditunjukkan 
pada Tabel 1.

Analisis terhadap hasil survei mengacu pembobotan pada Tabel 1, meliputi beberapa tahap sebagai berikut:

1. Penentuan Indeks Parameter (Indeks A, B, C, D) mengikuti Persamaan 1.

2. Penentuan Indeks Kelompok yang mencakup 4 parameter (Indeks 1, 2, 3) mengikuti Persamaan 2 - 4.

3. Penentuan Indeks Kesiapsiagaan tiap parameter $\left(\mathrm{IKS}_{\mathrm{A}}, \mathrm{IKS}_{\mathrm{B}}, \mathrm{IKS}_{\mathrm{C}}, \mathrm{IKS}_{\mathrm{D}}\right)$, mengikuti Persamaan $5-8$

4. Penentuan Indeks Kesiapsiagaan Total (IKS Total) yang merupakan gabungan dari $\mathrm{IKS}_{\mathrm{A}}, \mathrm{IKS}_{\mathrm{B}}, \mathrm{IKS}_{\mathrm{C}}$, dan $\mathrm{IKS}_{\mathrm{D}}$, mengikuti Persamaan 9.

Berdasarkan hasil perhitungan Indeks Kesiapsiagaan Total (IKS Total $)$ tersebut dapat ditentukan tingkat kesiapsiagaan komunitas sekolah yang terbagi menjadi 3 kategori, yaitu tingkat rendah, sedang, dan tinggi, berdasarkan Tabel 2 .

Tabel 1. Bobot parameter dalam \% (Hidayat dkk., 2011, dengan penyesuaian)

\begin{tabular}{cccccc}
\hline \multirow{2}{*}{ Kel. } & \multicolumn{5}{c}{ Parameter } \\
\cline { 2 - 5 } & A & B & C & D & \\
\hline 1 & - & 12 & 15 & 7 & 34 \\
2 & 31 & - & 8 & 3 & 42 \\
3 & 21 & - & 2 & 1 & 24 \\
\hline Jml & 52 & 12 & 25 & 11 & 100 \\
\hline
\end{tabular}

Tabel 2. Skor tingkat kesiapsiagaan

\begin{tabular}{lcl}
\hline Tingkat & Skor & kode \\
\hline Rendah & $0-33,3 \%$ & \\
Sedang & $33,4-66,6 \%$ & \\
Tinggi & $66,7-100 \%$ & \\
\hline
\end{tabular}

Dengan mengetahui tingkat kesiapsiagaan komunitas sekolah, maka dapat ditentukan jenis kegiatan yang tepat untuk dilaksanakan dalam usaha meningkatkan kesiapsiagaan komunitas Sekolah Dasar Muhammadiyah Banyuraden secara khusus, dan kesiapsiagaan daerah Kabupaten Sleman DIY secara umum.

Indeks $(A, B, C, D)=\frac{\text { skor riil }}{\text { jumlah skor maksimum }} \times 100$

Indeks $1=\frac{12}{34}$ Indeks $B+\frac{15}{34}$ Indeks $C+\frac{7}{34}$ Indeks $D$

Indeks $2=\frac{31}{42}$ Indeks $A+\frac{8}{42}$ Indeks $C+\frac{3}{42}$ Indeks $D$

Indeks $3=\frac{21}{24}$ Indeks $A+\frac{2}{24}$ Indeks $C+\frac{1}{24}$ Indeks $D$

$I K S_{A}=\frac{31}{52}$ Indeks $2+\frac{21}{52}$ Indeks 3

$I K S_{B}=$ Indeks 1

$I K S_{C}=\frac{15}{25}$ Indeks $1+\frac{8}{25}$ Indeks $2+\frac{2}{25}$ Indeks 3

$I K S_{D}=\frac{7}{11}$ Indeks $1+\frac{3}{11}$ Indeks $2+\frac{1}{11}$ Indeks 3

$I K S_{\text {Total }}=0,52 * I K S_{A}+0,12 * I K S_{B}+0,25 * I K S_{C}+0,11 * I K S_{D}$ 


\section{HASIL}

Hasil dari survei dibagi menjadi 3 kategori, sesuai kelompok kuosioner yang dibagikan, yaitu kelompok 1 (institusi), 2 (guru), dan 3 (murid).

\section{Hasil survei institusi}

Survei Institusi terdiri dari 1 paket kuosioner yang diisi oleh Kepala Sekolah, meliputi parameter B, C dan D. Hasil survei meliputi data singkat sekolah (Tabel 3) dan hasil skoring atau perhitungan indeks sekolah (Tabel 4). Tampak depan sekolah ditunjukkan pada Gambar 2.

\section{Hasil survei guru}

Kuosioner untuk guru (kelompok 2) diisi oleh semua guru, sebanyak 16 orang, yang terdiri dari $25 \%$ laki-laki dan $75 \%$ perempuan. Usia guru berkisar antara 23 46 tahun, dengan tingkat pendidikan sarjana, kecuali 1 orang lulusan D3. Hasil penilaian indeks parameter, meliputi parameter $\mathrm{A}, \mathrm{C}$, dan $\mathrm{D}$, ditunjukkan dalam Tabel 5.

\section{Hasil survei siwa}

Kuesioner kelompok 3 (untuk siswa) diisi oleh 72 anak, yang terdiri dari 39 siswa kelas IV dan 33 siswa kelas V. Usia anak berkisar antara 9 - 12 tahun, yang terdiri dari $51,4 \%$ laki-laki dan $48,6 \%$ perempuan. Hasil penilaian indeks parameter, meliputi parameter A, C, dan D, ditunjukkan dalam Tabel 6.

Tabel 3. Data singkat sekolah

\begin{tabular}{ll}
\hline \multicolumn{1}{c}{ Data } & \multicolumn{1}{c}{ Keterangan } \\
\hline Nama & SD Muhammadiyah Banyuraden \\
Alamat & Dukuh RT.06 RW.08 Banyuraden Gamping Sleman DIY \\
Kode Pos & 55293 \\
No. Telp. & 0274617118 \\
Kepala Sekolah & Madilah, S.Ag. \\
Jumlah Guru & 1 Kepala Sekolah, 16 guru + 1 tenaga administrasi \\
Jenis Bangunan & Dinding bata merah/batako dan perkuatan beton bertulang \\
Tingkat bangunan & Tingkat 1 dan 2 \\
Keterangan & Bangunan sudah mengikuti standar bangunan tahan gempa \\
\hline
\end{tabular}

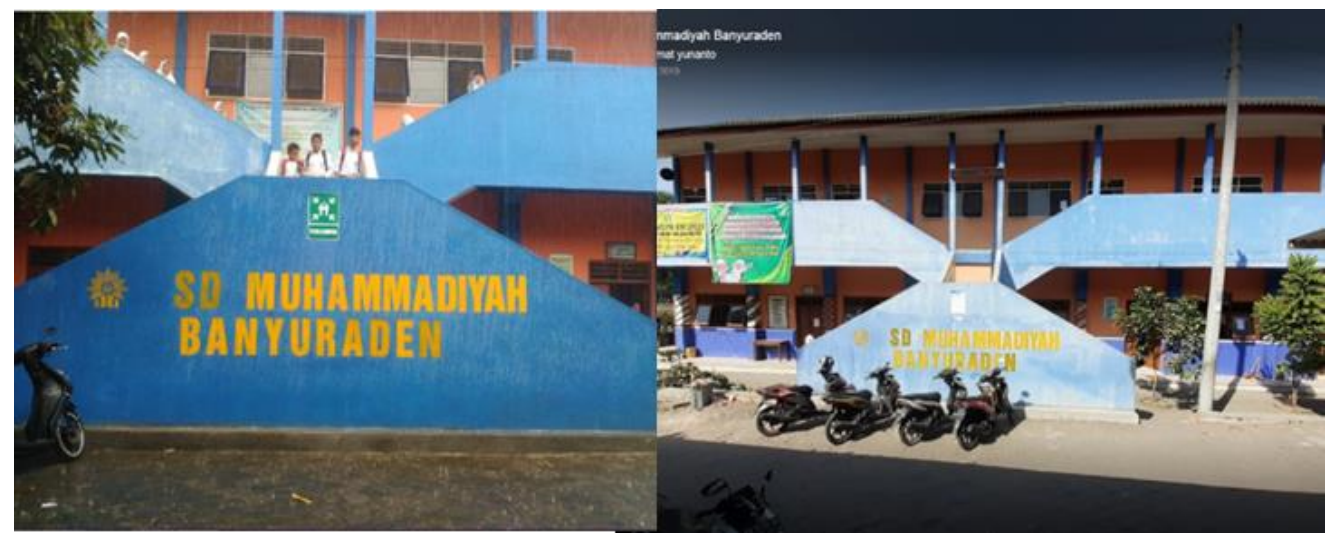

Gambar 2. Tampak depan bangunan SD Muhammadiyah Banyuraden 
Tabel 4. Indeks Parameter (Pr) kelompok 1 (institusi)

\begin{tabular}{|c|c|c|}
\hline $\operatorname{Pr}$ & Indeks & Keterangan \\
\hline B & 26,1 & $\begin{array}{l}\text { - Komunitas sekolah sudah mengetahui adanya peraturan-peraturan tentang } \\
\text { kesiapsiagaan dan sudah ada kebijakan sekolah tentang pengintegrasian } \\
\text { materi kesiapsiagaan ke dalam mata pelajaran yang relevan di sekolah. } \\
\text { - Belum terdapat: Gugus Siaga Bencana, program peningkatan pengetahuan } \\
\text { dan ketrampilan kesiapsiagaan untuk guru dan murid melalui kegiatan } \\
\text { ekstra kurikuler, latihan/simulasi evakuasi secara regular, serta alokasi } \\
\text { anggaran untuk kesiapsiagaan }\end{array}$ \\
\hline $\mathrm{C}$ & 31,25 & $\begin{array}{l}\text { - Sekolah tidak mempunyai back-up dokumen-dokumen penting yang } \\
\text { disimpan di tempat yang aman, namun sudah ada kesepakatan tempat- } \\
\text { tempat evakuasi dan membuat peta dan jalur evakuasi sekolah. } \\
\text { - Belum memiliki persiapan peralatan/perlengkapan evakuasi, latihan } \\
\text { simulasi/evakuasi, posko kesehatan sekolah, dan standar operasi untuk } \\
\text { pertolongan pertama serta prosedur tetap (Protap) evakuasi } \\
\text { - Sudah ada kegiatan dan tersedia bahan/ peralatan untuk pertolongan pertama } \\
\text { seperti pengadaan kotak obat-obat penting, mengaktifkan dokter kecil dan } \\
\text { Palang Merah Remaja (PMR) serta latihan pertolongan pertama. }\end{array}$ \\
\hline D & 37,0 & $\begin{array}{l}\text { - Sudah ada gugus tugas yang dapat dimanfaatkan utk kesiapsiagaan spt } \\
\text { Pramuka, UKS, dokter kecil, dan lain-lainnya. } \\
\text { - Tema pelatihan/seminar yang pernah diikuti oleh pimpinan/guru adalah } \\
\text { bencana, rencana evakuasi, sistem peringatan dini, sedangkan pertolongan } \\
\text { pertama dan simulasi evakuasi belum pernah diikuti. } \\
\text { - Sudah tersedia buku-buku tentang gempa, tapi belum tersedia poster, leaflet, } \\
\text { buku saku, komik, kliping koran dan VCD /kaset tentang gempa. } \\
\text { - Belum dilakukan simulasi/gladi evakuasi darurat bencana untuk komunitas } \\
\text { sekolah } \\
\text { - Sudah mendapat bantuan dari pemerintah dalam bentuk penyediaan bahan } \\
\text { dan materi, serta pelatihan simulasi dan evakuasi, tapi belum ada bantuan } \\
\text { dari fihak lain seperti LSM, NGO, dan perusahaan/ pihak swasta. }\end{array}$ \\
\hline
\end{tabular}

Tabel 5. Indeks Parameter (Pr) kelompok 2 (guru)

\begin{tabular}{|c|c|c|}
\hline $\operatorname{Pr}$ & Indeks & Keterangan \\
\hline A & 75,2 & $\begin{array}{l}\text { - Sebagian besar guru sudah mengetahui pengertian dan kejadian yang dapat } \\
\text { menyebabkan terjadinya bencana alam, bencana gempabumi dan sifat- } \\
\text { sifatnya, beserta cara-cara yang harus dilakukan jika terjadi gempa. } \\
\text { - } 69 \% \text { guru pernah memberikan pelajaran kepada murid tentang gempa. } \\
\text { - } 75 \% \text { guru pernah memberikan informasi kepada murid tentang gempa. } \\
\text { - Sumber informasi gempa yang diterima guru ditunjukkan dalam Gambar } 3 \text {. } \\
\text { TV merupakan sumber informasi yang paling populer. }\end{array}$ \\
\hline $\mathrm{C}$ & 56,3 & $\begin{array}{l}\text { - 87,5\% guru sudah memiliki persiapan untuk mengantisipasi terjadinya } \\
\text { gempa, namun belum ada satupun yang mengikat rak-rak buku ke dinding. } \\
\text { - } 43-81 \% \text { guru sudah mengetahui tindakan yang harus dilakukan jika ada } \\
\text { gempa, meskipun } 68,8 \% \text { belum pernah melakukan simulasi evakuasi } \\
\text { - } 75 \% \text { tidak terlibat dalam gugus siaga bencana. }\end{array}$ \\
\hline $\mathrm{D}$ & 48,1 & $\begin{array}{l}\text { - } 18,8 \% \text { guru belum pernah mengikuti pelatihan kebencanaan dan } \\
\text { memberikan pengetahuan kesiapsiagaan kepada siswa } \\
\text { - } 37,5 \% \text { guru belum pernah mempraktekkan kegiatan kesiapsiagaan bersama } \\
\text { siswa, seperti pertolongan pertama dan evakuasi. }\end{array}$ \\
\hline
\end{tabular}


Tabel 6. Indeks Parameter (Pr) kelompok 3 (siswa)

\begin{tabular}{|c|c|c|}
\hline $\operatorname{Pr}$ & Indeks & Keterangan \\
\hline A & 70,7 & $\begin{array}{l}\text { - Sebagian besar siswa sudah mengetahui pengertian dan kejadian yang } \\
\text { menimbulkan bencana alam, gempa dan sifat-sifatnya, apa yang harus } \\
\text { dilakukan jika gempa terjadi saat jam sekolah, serta tindakan yang } \\
\text { diperlukan untuk mempersiapkan diri jika ada gempa } \\
\text { - Pengetahuan tentang gempa paling banyak }(93,1 \%) \text { diperoleh dari media } \\
\text { cetak (koran, majalah, tabloid dll) } \\
\text { - } 80,6 \% \text { siswa pernah mendapatkan pelajaran tentang gempa di sekolah, } \\
\text { dengan tema penyelamatan dan evakuasi }(70,8 \%)\end{array}$ \\
\hline $\mathrm{C}$ & $47,6 \%$ & $\begin{array}{l}\text { - 22-75\% siswa mengetahui persiapan yang harus dilakukan sebelum gempa } \\
\text { - 22-87,5\% siswa mengetahui barang-barang yang harus diselamatkan jika } \\
\text { ada gempa } \\
\text { - Materi gempa paling banyak diperoleh siswa }(52,8 \%) \text { melalui buku } \\
\text { - } 69,4 \% \text { siswa mengatakan bahwa kotak P3K dan obat-obat penting sudah } \\
\text { tersedia di sekolah } \\
\text { - } 81,9 \% \text { siswa tidak mengetahui adanya kelompok siaga bencana di sekolah } \\
\text { - } 84,7 \% \text { siswa mengatakan bahwa belum pernah dilakukan simulasi evakuasi } \\
\text { gempa di sekolah }\end{array}$ \\
\hline D & $34,7 \%$ & $\begin{array}{l}\text { - 93,1\% siswa belum pernah mengikuti kegiatan P3K, dokter kecil, dan PMR } \\
\text { - 19,4\% siswa belum pernah mengikuti latihan pramuka } \\
\text { - 86,1\% siswa belum pernah mengikuti latihan simulasi evakuasi } \\
\text { - } 62,5 \% \text { siswa belum pernah mengikuti ceramah kebencanaan }\end{array}$ \\
\hline
\end{tabular}

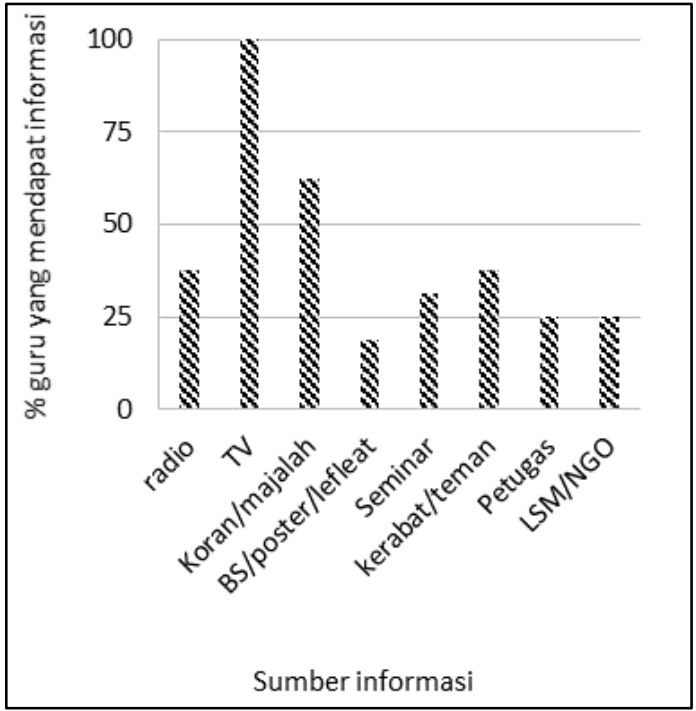

Gambar 3. Sumber informasi tentang gempa yang diterima guru.

\section{PEMBAHASAN}

Setelah diketahui Indeks tiap parameter pada masing-masing kelompok, selanjutnya dapat dihitung Indeks
Kesiapsiagaan kelompok, tiap parameter dan total mengikuti Persamaan 2-9. Hasil perhitungannya adalah sebagai berikut:

Indeks $1=30,6$

Indeks $2=69,7$

Indeks $3=67,3$

$\mathrm{IKS}_{\mathrm{A}}=68,7$

$\mathrm{IKS}_{\mathrm{B}}=30,6$

$\mathrm{IKS}_{\mathrm{C}}=46,0$

$\mathrm{IKS}_{\mathrm{D}}=44,6$

$\mathrm{IKS}_{\text {Total }}=55,8$

Berdasarkan hasil perhitungan di atas, diketahui indeks kesiapsiagaan total (IKS Total $)$ SD Muhammadiyah Banyuraden adalah 55,8. Indeks kesiapsiagaan total ini merupakan gabungan dari indeks 
kesiapsiagaan parameter $\mathrm{A}, \mathrm{B}, \mathrm{C}$, dan $\mathrm{D}$, yang besarnya berbeda-beda. Berdasarkan indeks tiap parameter dan indeks total, dapat ditentukan tingkat kesiapsiagaannya dengan mengacu pada Tabel 2 .

Apabila diperhatikan indeks kesiapsiagaan tiap parameter, maka indeks kesiapsiagaan parameter $\mathrm{A}\left(\mathrm{IKS}_{\mathrm{A}}\right)$ yaitu pengetahuan tentang fenomena gempa memiliki skor tertinggi $(68,7)$ dan tergolong pada tingkat kesiapsiagaan tinggi. Hal ini menunjukkan bahwa secara personal, guru dan murid sudah memiliki pengetahuan yang cukup baik tentang fenomena gempa. Indeks parameter terendah adalah $\mathrm{IKS}_{\mathrm{B}}$, yaitu parameter kebijakan dan panduan, dengan indeks sebesar 30,6 dan tergolong pada tingkat kesiapsiagaan rendah. Hal itu menunjukkan bahwa kebijakan dan panduan tentang kesiapsiagaan dari institusi masih kurang dan harus ditingkatkan. Adapun Indeks kesiapsiagaan parameter C dan D $\left(\right.$ IKS $_{C}$ dan IKS D $_{\text {) sebesar }} 46$ dan 44,5 tergolong pada tingkat kesiapsiagaan sedang, yaitu rencana tanggap darurat dan mobilisasi sumber daya. Sedangkan tingkat kesiapsiagaan total dapat digolongkan pada tingkat sedang, dengan indeks 55,8.

Secara ringkas tingkat kesiapsiagaan masing-masing parameter dan tingkat kesiapsiagaan total ditunjukkan dalam Tabel 7.
Tabel 7. Tingkat kesiapsiagaan tiap parameter $(\operatorname{Pr})$

\begin{tabular}{|c|c|c|}
\hline \multirow{2}{*}{$\operatorname{Pr}$} & \multicolumn{2}{|c|}{ Tingkat kesiapsiagaan } \\
\hline & rendah sedang & tinggi \\
\hline A & & \\
\hline B & & \\
\hline $\mathrm{C}$ & & \\
\hline $\mathrm{D}$ & & \\
\hline Total & & \\
\hline
\end{tabular}

Berdasarkan hasil ini, maka perlu dilakukan kegiatan peningkatan kesiapsiagaan di SD Muhammadiyah Banyuraden agar dapat mencapai tingkat kesiapsiagaan tinggi dengan skor di atas 66,7. Bentuk kegiatan yang tepat dapat ditentukan dengan memperhatikan hasil survei yang telah dilakukan, yaitu diutamakan untuk meningkatkan indeks parameter B, C, dan D. Beberapa kegiatan yang disarankan ditunjukkan dalam Tabel 8. Usulan kegiatan tersebut diambil berdasarkan data-data yang diperoleh dari hasil survei, dengan memprioritaskan pada parameter yang memiliki indeks kecil.

Kegiatan - kegiatan yang diusulkan pada Tabel 8 ini diharapkan dapat meningkatkan tingkat kesiapsiagaan komunitas SD Muhammadiyah Banyuraden di masa mendatang, sehingga apabila terjadi gempa pada saat jam sekolah, seluruh komunitas sekolah diharapkan memiliki kesiapsiagaan yang baik. Dengan demikian, diharapkan jatuhnya korban dan kerugian akibat bencana gempa dapat dicegah atau diminimalkan. 
Tabel 7. Saran kegiatan peningkatan kesiapsiagaan

\begin{tabular}{ll}
\hline Sasaran & \multicolumn{1}{c}{ Bentuk Kegiatan } \\
\hline Institusi & 1. Pembentukan gugus siaga bencana \\
& 2. Penyusunan kegiatan pendidikan kebencanaan, simulasi evakuasi, dan \\
& pembuatan jalur evakuasi \\
& 3. Alokasi anggaran untuk kegiatan kesiapsiagaan \\
& 4. Back-up dokumen penting \\
& 5. Penyusunan SOP dan Protap evakuasi \\
& 6. Pengadaan poster, buku saku, VCD, dan sarana informasi kebencanaan \\
\hline Guru & 1. Menyelenggarakan pelatihan/ seminar guru tentang pertolongan \\
& pertama dan evakuasi \\
& 2. Melibatkan guru dalam gugus siaga bencana \\
& 3. Diselenggarakan pelatihan simulasi evakuasi untuk guru bersama \\
& murid \\
\hline Murid & 1. Meningkatkan pendidikan kebencanaan untuk siswa \\
& 2. Diselenggarakan simulasi evakuasi guru dan siswa \\
& 3. Sosialisasi sarana-sarana siaga bencana kepada siswa \\
& 4. Melibatkan lebih banyak siswa dalam kegiatan P3K, dokter kecil dan \\
& palang Merah Remaja (PMR)
\end{tabular}

Tampak pada tabel 7 , peningkatan pendidikan kebencanaan untuk siswa adalah salah satu prioritas yang wajib dilakukan institusi kepada siswa. Integrasi materi kesiapsiagaan dalam pembelajaran diketahui meningkatkan antusiasme siswa dalam memahami dan mengikuti informasi mengenai bencana (Ayub dkk, 2019).

Kegiatan-kegiatan sebagaimana dirumuskan pada tabel 7 adalah salah satu upaya dalam meningkatkan pemahaman mengenai kesiapsiagaan bencana. Hal ini menunjukkan bahwa menyiapkan mental komunitas sekolah baik institusi, guru, dan siswa adalah hal yang sangat penting (Utama dkk, 2018).

\section{SIMPULAN}

Berdasarkan hasil penilaian, tingkat kesiapsiagaan komunitas

Muhammadiyah Banyuraden tergolong sedang dengan indeks kesiapsiagaan total 55,8. Kegiatan peningkatan kesiapsiagaan hendaknya dilakukan dengan memprioritaskan pada parameter kebijakan dan panduan, rencana tanggap darurat, dan mobilisasi sumber dana.

\section{SARAN}

Kegiatan yang dirumuskan dan disarankan menjadi prioritas dilaksanakan untuk meningkatkan indeks kesiapsiagaan bencana SD Muhammadiyah Banyuraden adalah sebagai berikut:

1. Institusi diharapkan dapat membentuk gugus siaga bencana;

2. Institusi diharapkan dapat menyusun SOP dan Prosedur tetap Evakuasi; 
3. Institusi diharapkan mulai melakukan sosialisasi melalui buku saku, video, dan sarana informasi kebencanaan;

Guru dan siswa terlibat dalam pelatihan lanjutan mengenai kesiapsiagaan bencana dan dilakukan simulasi evakuasi.

\section{UCAPAN TERIMA KASIH}

Tim pengabdi mengucapkan terima kasih atas dukungan penuh dari Universitas Muhammadiyah Yogyakarta melalui Lembaga Penelitian, Publikasi, dan Pengabdian masyarakat (LP3M) sehingga kegiatan pengabdian kepada masyarakat ini dapat berjalan dengan baik.

\section{DAFTAR PUSTAKA}

Amri, A. (2017). Pendidikan Tangguh Bencana (P. D. Puspitawati, S. R. Pantjastuti, L. Kurniawan, Praptono, \& Y. Tebe, Eds.). Sekretariat Nasional SPAB.

Ayub, S., Kosim, K., Gunada, I. W., \&

Zuhdi, M. (2019). Model

Pembelajaran Kesiapsiagaan Bencana

Gempabumi Di Sekolah Dasar.

ORBITA: Jurnal Kajian, Inovasi dan

Aplikasi Pendidikan Fisika, 5(2), 65.

https://doi.org/10.31764/orbita.v5i2.1

187

BNPB. (2016). Penurunan Indeks Risiko Bencana di Indonesia.
Faizah, R., Diana, W., \& Hartono, E. (2019). Peningkatan Ketangguhan Masyarakat Dusun Godegan Jamuskauman Ngluwar Magelang Jawa Tengah. Adimas: Jurnal Pengabdian Kepada Masyarakat, $3(2)$,

https://doi.org/10.24269/adi.v3i2.16 32

Hidayat, D., Widayatun, Hartana, P., Triyono, \& Kusumawati, T. (2011). Panduan Mengukur Tingkat Kesiapsiagaan Masyarakat dan Komunitas Sekolah. Pusat Penelitian Oseanografi LIPI.

Kemendikbud. (2019). Data Pokok Pendidikan Dasar dan Menengah Direktorat Jenderal Pendidikan Dasar dan Menengah, Kementerian Pendidikan dan Kebudayaan: SD Muhammadiyah Banyuraden. https://dapo.dikdasmen.kemdikbud. go.id/sekolah/E16EB346A585A090 $607 \mathrm{C}$

Kurniawan, L., Triutomo, S., Yunus, R., Amri, Mohd. R., \& Hartyanto, A. A. (2014). IRBI, Indeks Risiko Bencana Indonesia 2013. Direktorat Pengurangan Risiko Bencana, Deputi Bidang Pengurangan dan Kesiapsiagaan BNPB.

Lesmana, C., \& Purborini, N. (2015). Kesiapsiagaan Komunitas Sekolah 
dalam Menghadapi Bencana di

Kabupaten Magelang. Jurnal Teknik

Sipil, 11(1), 15-28.

Undang-undang No. 24 Tahun 2007 tentang

Penanggulangan Bencana, UU No.

24 Th. 2007 (2007).

Utama, R. I., Syah, N., Rifwa, F., Sari, N.

M., \& Yandra, M. (2018). Penerapan

dan Sosialisasi Sekolah Siaga

Bencana Bagi Anak-anak Sekolah

Dasar di Kabupaten Agam. Cived, 5(4), 4-8. 